\title{
Influence of production process design on inclusion bodies protein: the case of an Antarctic flavohemoglobin
}

\author{
Ermenegilda Parrilli, ${ }^{1,2}$, Maria Giuliani ${ }^{1}$, Gennaro Marino ${ }^{1,2}$, Maria Luisa Tutino ${ }^{1,2^{*}}$
}

\begin{abstract}
Background: Protein over-production in Escherichia coli often results in formation of inclusion bodies (IBs). Some recent reports have shown that the aggregation into IBs does not necessarily mean that the target protein is inactivated and that IBs may contain a high proportion of correctly folded protein. This proportion is variable depending on the protein itself, the genetic background of the producing cells and the expression temperature. In this paper we have evaluated the influence of other production process parameters on the quality of an inclusion bodies protein.

Results: The present paper describes the recombinant production in Escherichia coli of the flavohemoglobin from the Antarctic bacterium Pseudoalteromonas haloplanktis TAC125. Flavohemoglobins are multidomain proteins requiring FAD and heme cofactors. The production was carried out in several different experimental setups differing in bioreactor geometry, oxygen supply and the presence of a nitrosating compound. In all production processes, the recombinant protein accumulates in IBS, from which it was solubilized in non-denaturing conditions. Comparing structural properties of the solubilized flavohemoglobins, i.e. deriving from the different process designs, our data demonstrated that the protein preparations differ significantly in the presence of cofactors (heme and FAD) and as far as their secondary and tertiary structure content is concerned.

Conclusions: Data reported in this paper demonstrate that other production process parameters, besides growth temperature, can influence the structure of a recombinant product that accumulates in IBs. To the best of our knowledge, this is the first reported example in which the structural properties of a protein solubilized from inclusion bodies have been correlated to the production process design.
\end{abstract}

\section{Background}

Protein over-production in Escherichia coli (E. coli) often results in formation of inclusion bodies (IBs). Aggregation most probably occurs as a consequence of interactions among the newly-formed folding intermediates which expose hydrophobic residues at their surface [1]. For a long time it was believed that IBs were compact, insoluble aggregates of misfolded proteins [2], remaining in the cell as biologically inactive deposits.

However, some recent reports have shown that the aggregation into IBs does not necessarily mean that the target protein is inactivated [3,4]. Structural data

\footnotetext{
*Correspondence: tutino@unina.it

'Department of Organic Chemistry and Biochemistry, Università degli studi di Napoli Federico II - Complesso Universitario M.S. Angelo via Cinthia 4, 80126, Naples, Italy
}

(C) 2010 Parrilli et al; licensee BioMed Central Ltd. This is an Open Access article distributed under the terms of the Creative Commons Attribution License (http://creativecommons.org/licenses/by/2.0), which permits unrestricted use, distribution, and reproduction in any medium, provided the original work is properly cited. collected from many model proteins revealed the presence of significant proportions of native-like secondary structure in IBs proteins [5,6]. Consequently, it is not surprising that the analysis of the biological properties of IBs formed by enzymes demonstrated in some cases the occurrence of enzymatic activity inside the IBs $[3,7]$. These evidences introduced the concept that IBs are composed, at least partially, by functional polypeptides, whose deposition is necessarily driven by discrete aggregation determinants, that act irrespective of the global folding state of the protein [8]. It has been observed that IBs containing a high proportion of correctly folded protein can be easily solubilized under non-denaturing conditions [9] by using mild detergents or polar solvents, widely preserving the target protein folding. 
The prevalence and extent of native structure and biological activity of IB proteins is variable depending on the protein itself, the genetic background of the producing cells and the expression temperature $[6,10]$.

Flavohemoglobins (flavoHbs) have been identified in a number of bacteria and yeasts [11]. These proteins are characterized by a modular structure, where a N-terminal hemoglobin domain, displaying a classical threeover-three $\alpha$-helical sandwich motif around a single heme b [12], is linked to a C-terminal FAD-containing reductase domain which resembles ferredoxin reductase [13]. The flavoHbs C-terminal domain binds $\mathrm{NAD}(\mathrm{P}) \mathrm{H}$ and transfers electrons to the heme in the globin domain via FAD $[14,15]$.

It is generally believed that flavohemoglobins provide protection against $\mathrm{NO}$ and related reactive nitrogen species although the exact mechanism of action is still under debate [16-21].

A flavoHb encoding gene (PSHAa2880) was identified by in silico genome analysis of the Antarctic Gramnegative marine eubacterium Pseudoalteromonas haloplanktis TAC125 (P. haloplanktis TAC125) [22]. In the present paper, the recombinant production of the psychrophilic flavoHb (hereinafter called $P h f l a v o H b)$ in $E$. coli cells was carried out in several different experimental setups in order to identify the best production condition. Indeed, previously reported results on $E$. coli flavoHb demonstrated that the heterologous over-production of flavoHb may lead to host cell damage due to the action of flavoHb as a potent generator of products of oxygen radical partial reduction (i.e., superoxide and peroxide) [23-25]. Due to the expected toxicity of the recombinant product, flavoHb recombinant productions were carried out exploring several expression systems and/or microbial cell factories, with different results [26]. Amongst many other examples reported in literature, recombinant production of $E$. coli flavoHb in $E$. coli was obtained in absence of oxygen and in presence of nitrosating compound, an experimental setup in which the hmp gene expression is physiologic and the flavoHb activity is required [27].

Starting from the above information, in the present work, the recombinant production of the flavoHb from the Antarctic Gram-negative bacterium P. haloplanktis TAC125 [22] was performed in E. coli cells exploring some conditions differing in presence of a nitrosating compound and in $\mathrm{O}_{2}$ supply.

All production processes resulted in the accumulation of the recombinant protein in IBs, from which it was solubilized in non-denaturing conditions. Comparing structural properties of the solubilized PhflavoHbs, i.e. deriving from the different production processes, our data demonstrated that the protein preparations differ significantly in the presence of cofactors (heme and
FAD) and in their secondary and tertiary structure, demonstrating the impact of the specific production process design on the quality of inclusion bodies protein.

\section{Results}

Recombinant production of $P$. haloplanktis TAC125 flavohemoglobin in E. coli cells resulted in full deposition of the protein in the inclusion bodies

The PSHAa2880 gene was PCR amplified to suitably introduce NdeI and SalI restriction sites, and cloned into $\mathrm{pET} 22 \mathrm{~b}$ vector corresponding sites, thus generating the recombinant pET22b-2880 plasmid.

E. coli BL21(DE3) cells were transformed with the recombinant vector and, keeping in mind that proteins coming from psychrophilic micro-organisms are often characterized by a moderate to extreme thermal-lability [28], the production of the PhflavoHb was carried out at $20^{\circ} \mathrm{C}$. However, two different production process setups were explored. First, E. coli BL21(DE3)(pET22b-2880) recombinant cells were grown in a $7.5 \mathrm{~L}$ automatic fermenter, in which the recombinant mesophilic cells were grown aerobically at $20^{\circ} \mathrm{C}$ till the culture density reached the value of $0.6 \mathrm{OD}$ at $600 \mathrm{~nm}$. Induction was then performed by IPTG, in the following conditions: i) addition of heme and FAD precursors (i.e. D-aminolevulinic acid, $\mathrm{FeCl}_{3}$, and riboflavin); ii) addition of the nitrosating compound sodium nitroprusside (SNP), and iii) in microaerophilic conditions (dissolved oxygen tension always below $5 \%$ of saturation). Microareophilic conditions were achieved by stopping air supply during the next 16-18 hr of fermentation. The second experimental condition consisted in growing recombinant cells in shake flask at $20^{\circ} \mathrm{C}$ until the culture absorbance at 600 $\mathrm{nm}$ reached $0.6 \mathrm{OD}$, when the protein production was induced in the same conditions as in automatic fermenter but without SNP and in aerobic conditions.

Then, cells coming from the above production processes were analyzed looking for production and soluble/insoluble distribution of the recombinant protein by cell fractionation followed by SDS-PAGE analysis. Both production processes resulted in the total deposition of recombinant flavohemoglobin as cytosolic inclusion bodies (IBs), that were called flask-flavoHb IBs and ferm-flavoHb IBs if derived from cells grown in shake flasks or in fermenter, respectively.

\section{Recombinant $P$. haloplanktis TAC125 flavohemoglobin is solubilized from inclusion bodies by non-denaturing solutions}

Treatment of $P$. haloplanktis TAC125 flavo-Hb IBs with different non-denaturing solvents such as low concentration of mild detergents or polar solvents was applied to the recovery of the recombinant protein in solution. 
Identical aliquots of flask-flavoHb IBs and ferm-flavoHb IBs were incubated overnight at $4^{\circ} \mathrm{C}$ with different nondenaturing solutions (i.e. buffered solutions containing $0.2 \%$ N-lauroyl sarcosine, or $5 \%$ DMSO, or $5 \% n$-propanol, or $0.5 \%$ Triton X-100, or $1 \%$ Na-deoxycholate). Solubilized proteins were then separated from the insoluble matter by a centrifugation step and subjected to SDS-PAGE analysis. As shown in figure 1, both ferm-
flavoHb IBs (panel A) and flask-flavoHb IBs (panel B) are partially solubilized in all tested conditions, although the solubilization yields (defined as the percentage of solubilized proteins relative to the total amount contained into the IBs sample) result to be quite different (Table 1). Indeed, best recovery in solution was obtained in N-lauroyl sarcosine either for ferm-flavoHb IBs or flask-flavoHb IBs (Table 1), but the corresponding
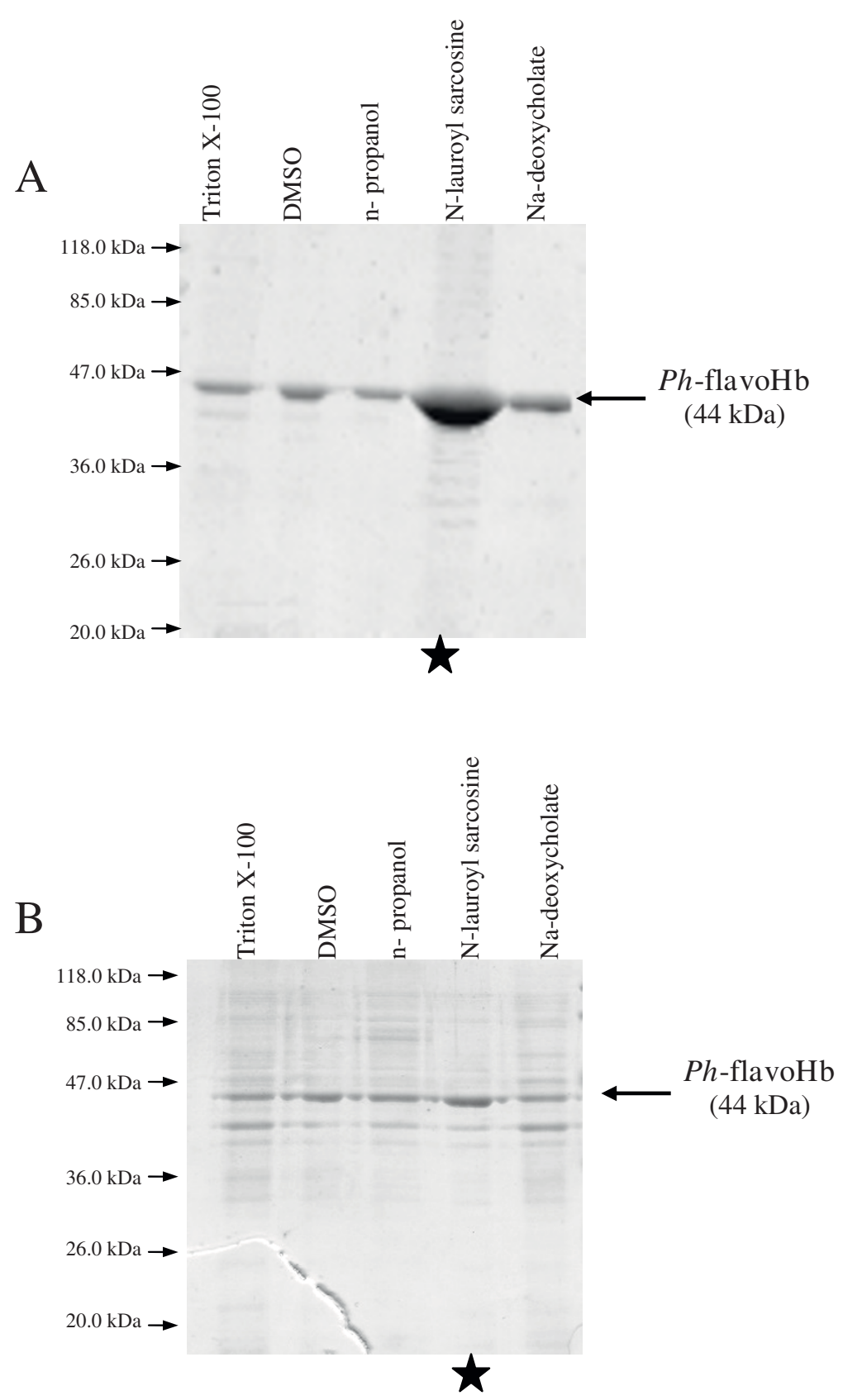

Figure 1 Solubilization of flavoHb inclusion bodies produced in automatic fermenter (panel A) and shake flask (panel B). Same amounts of IBs were re-suspended in $40 \mathrm{mM}$ Tris/ $\mathrm{HCl}$, pH 8.0 buffer containing different non denaturing agents. Same volumes of solubilized proteins were analysed by SDS-PAGE. Black star indicates that the loaded sample corresponds to one tenth of the other samples. 
Table 1 Percentage of solubilization of IBs in different solvents

\begin{tabular}{|c|c|c|}
\hline \multirow[b]{2}{*}{ Solubilization solution } & \multicolumn{2}{|c|}{$\%$ solubilized protein } \\
\hline & ferm-flavoHb & flask-flavoHb \\
\hline $\begin{array}{c}0.5 \% \text { Triton } \mathrm{X}-100 \text { in } 40 \mathrm{mM} \\
\text { Tris/ } \mathrm{HCl}, \mathrm{pH} 8.0\end{array}$ & $8 \pm 0.6$ & $10 \pm 0.9$ \\
\hline $5 \%$ DMSO in $40 \mathrm{mM}$ Tris/HCl, pH 8.0 & $9 \pm 0.9$ & $5 \pm 0.4$ \\
\hline $\begin{array}{l}\text { 5\% di n-propanol in } 40 \mathrm{mM} \\
\text { Tris/HCl, pH } 8.0\end{array}$ & $6 \pm 0.7$ & $5 \pm 0.1$ \\
\hline $\begin{array}{c}0.2 \% \text { N-lauroyl sarcosine in } 40 \mathrm{mM} \\
\text { Tris } / \mathrm{HCl}, \mathrm{pH} 8.0\end{array}$ & $95 \pm 1.0$ & $57 \pm 0.8$ \\
\hline $\begin{array}{c}\text { 1\% Na-deoxycholate in } 40 \mathrm{mM} \\
\text { Tris/HCl, pH } 8.0\end{array}$ & $22 \pm 1.5$ & $12 \pm 0.3$ \\
\hline
\end{tabular}

Percentage of solubilization of IBs in different solvents was calculated using as $100 \%$ the protein concentration obtained dissolving IBs in urea $8 \mathrm{M}$ and comparing this value with the protein concentration of samples obtained by treatment with different solvents. Evaluation of protein concentration was obtained by measuring the absorbance at $280 \mathrm{~nm}$ (Abs280).

solubilization yields exceed $95 \%$ in case of ferm-flavoHb IBs, while only about fifty percent of total proteins contained into IBs from flask culture went in solution. It is worth mentioning that in figure 1 the loaded amount of $\mathrm{N}$-lauroyl sarcosine solubilized samples correspond to one tenth of the other samples.

The two solubilized IBs preparations also differ in their respective protein composition. As shown in figure 1, flask-flavoHb IBs seems to contain several proteins other than flavoHb (panel B), while IBs produced in fermenter contains almost only the psychrophilic recombinant protein (panel A).

\section{Structural comparison of recombinant $P$. haloplanktis TAC125 ferm- and flask-flavoHb}

Flavohemoglobins extracted from either flask-flavoHb IBs (flask-flavoHb) or ferm-flavoHb IBs (ferm-flavoHb) were subjected to further analyses to investigate the presence of the two protein cofactors, i.e. heme and FAD.

Absorption spectra of heme-containing proteins are characterized by the presence of Soret signal, a peak centred at about $413 \mathrm{~nm}$. Therefore, UV/VIS absorption spectra of each solubilized flavoHb were recorded, and their respective spectra regions between 380 and 450 $\mathrm{nm}$ are shown in figure 2. Only the ferm-flavoHb spectrum is characterized by the presence of a typical Soret signal, centred at about $413 \mathrm{~nm}$ (Figure 2).

Then, the presence of the FAD cofactor in flask-flavoHb and ferm-flavoHb proteins was investigated by fluorescence measurements. In detail, emission spectra between $500 \mathrm{~nm}$ and $600 \mathrm{~nm}$, exciting at $450 \mathrm{~nm}$, were recorded and are shown in figure 3 . An emission signal at $520 \mathrm{~nm}$, which is indicative of the presence of the FAD cofactor, was only detected in the ferm-flavoHb fluorescence spectrum (Figure 3).

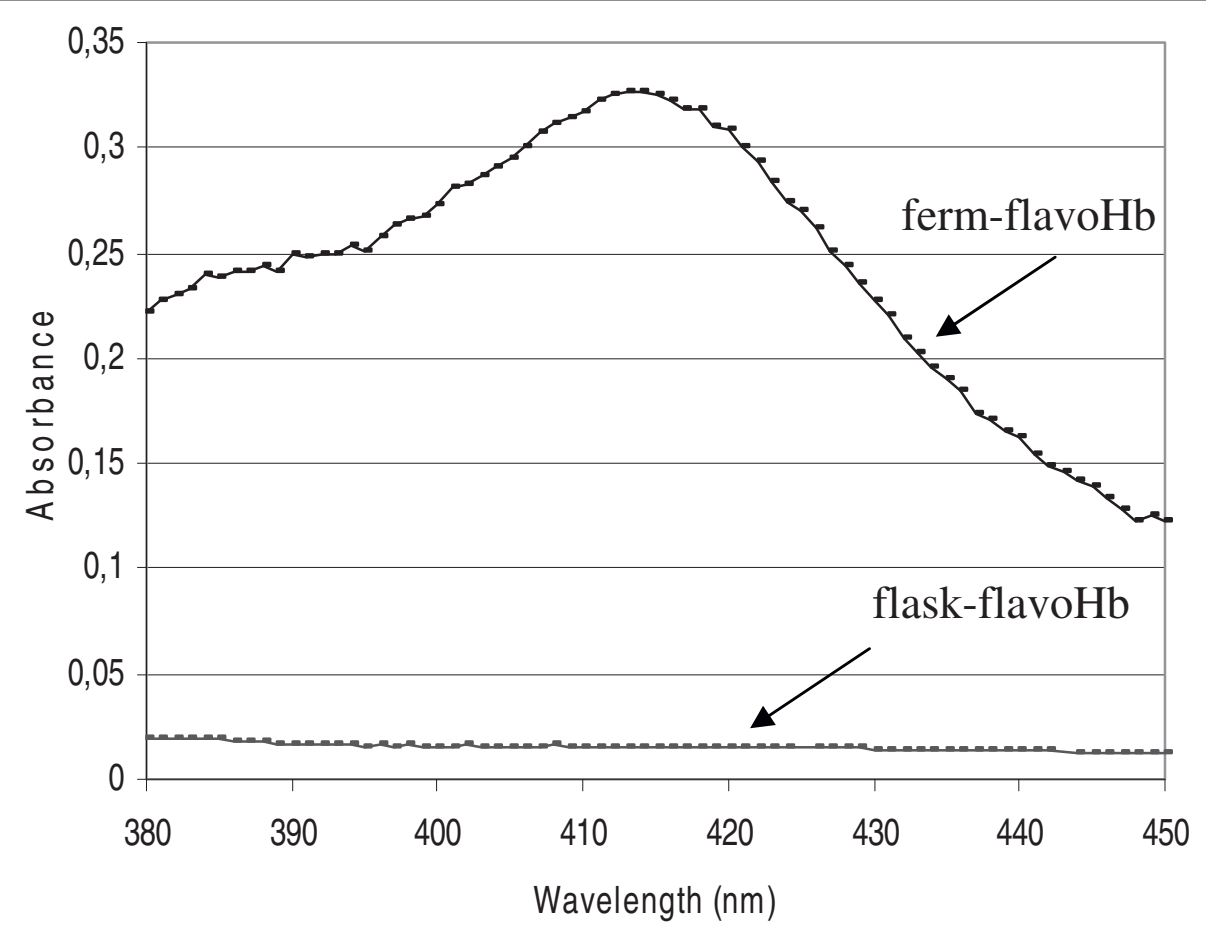

Figure 2 Absorption spectra of ferm-flavoHb and flask-flavoHb. Absorption spectra of cold-adapted flavohemoglobin extracted from IBs produced in fermenter (ferm-flavoHb) and in flask (flask-flavoHb). The spectra were recorded in $0.2 \%$ N-lauroyl sarcosine, $40 \mathrm{mM} \mathrm{Tris/HCl} \mathrm{pH} \mathrm{8.0,}$ and the proteins concentration was $2 \mu \mathrm{M}$. 


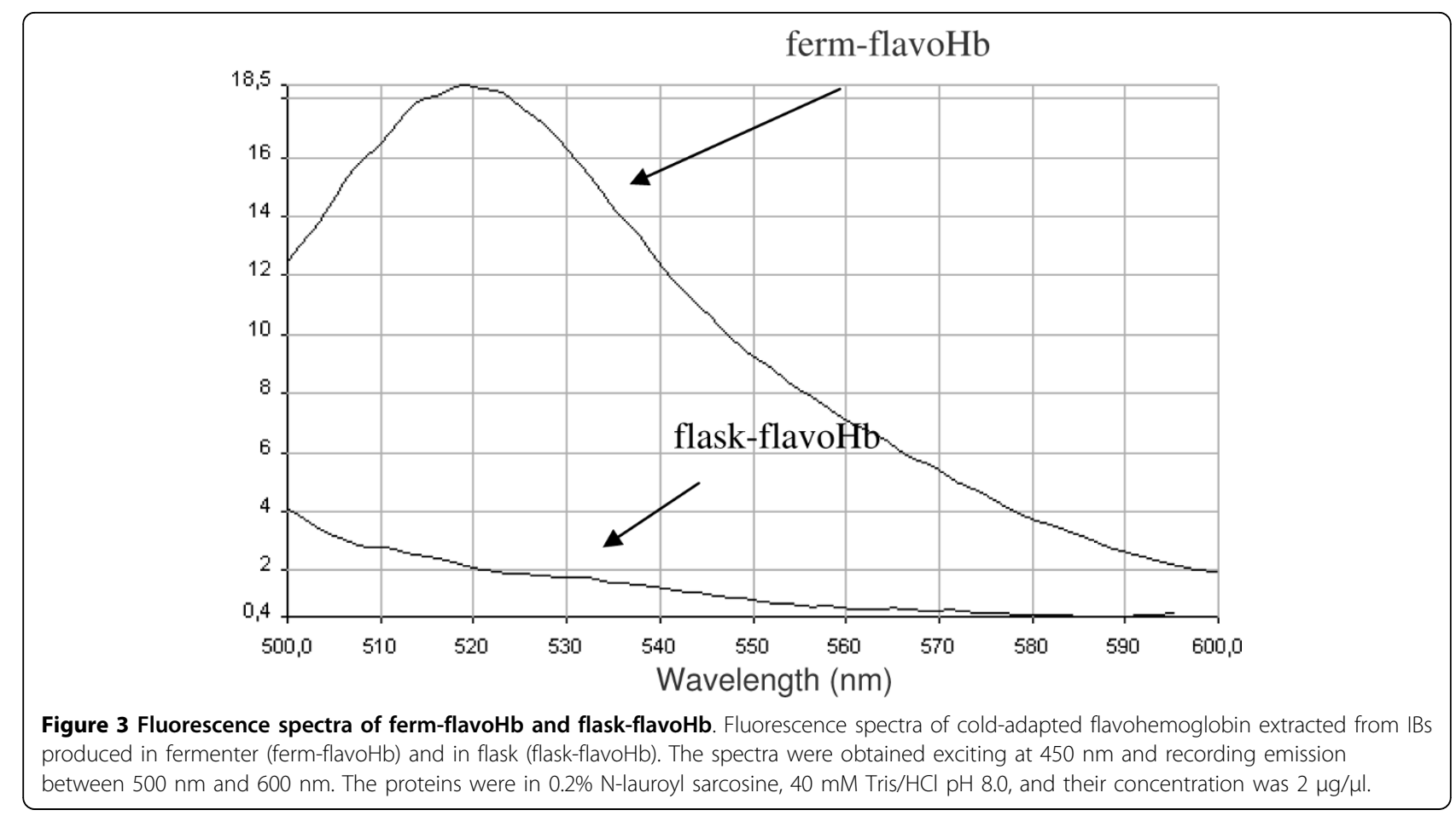

To explore the secondary structure of flask-flavoHb and ferm-flavoHb proteins, circular dichroism measurements were performed. As shown in figure 4, both proteins display secondary structure, although not identical since the two recorded CD spectra are clearly not superimposable. The collected CD data were used to calculate the percentage of $\alpha$-helix, $\beta$-sheets and random coil for each protein (by using the software $\mathrm{K} 2 \mathrm{~d}$, accessible through the site http://www.emblheidelberg.de/ andrade/k2d[29,30]). As shown in table 2 , the two proteins differ significantly in their secondary structure content, and the ferm-flavoHb protein is predicted to have a higher content of either $\beta$-sheets or $\alpha$-helix.

The structural comparison between flask-flavoHb and ferm-flavoHb proteins was then extended to the study of fluorescence emission spectra of tryptophan residues (3 Trp residues are present in the PhflavoHb sequence). Emission spectra in the range between $310 \mathrm{~nm}$ and 500 $\mathrm{nm}$, exciting at $295 \mathrm{~nm}$, were recorded and are presented in figure 5 . Both proteins display an emission spectrum $\lambda_{\max }$ close to $338 \mathrm{~nm}$, indicating that Trp

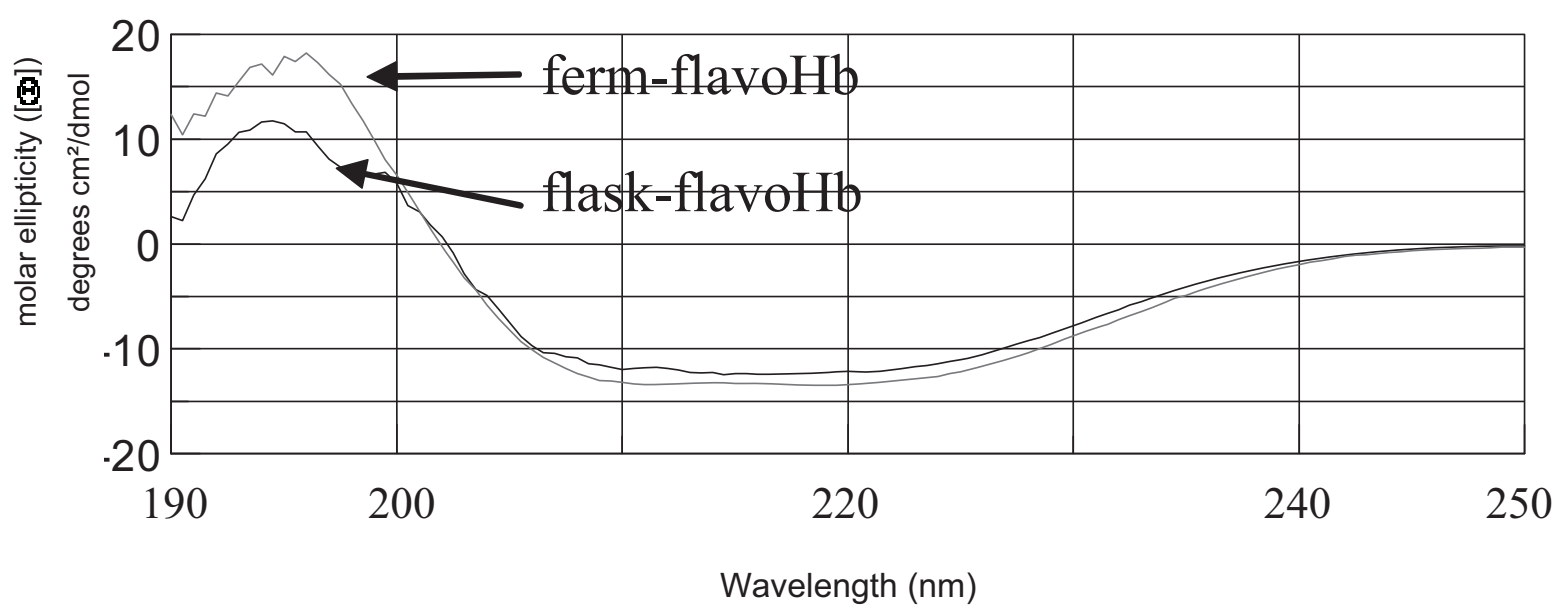

Figure $4 \mathrm{CD}$ analysis of ferm-flavoHb and flask-flavoHb. $\mathrm{CD}$ analysis of ferm-flavoHb (A) and flask-flavoHb (B). The CD spectra were recorded in phosphate buffer $40 \mathrm{mM} \mathrm{pH} 8.0$ at $25^{\circ} \mathrm{C}$, the proteins concentration was $100 \mathrm{ng} / \mu \mathrm{l}$. 
Table 2 Percentage of calculated secondary structures of ferm-flavoHb and flask-flavoHb

\begin{tabular}{ccc}
\hline & \multicolumn{2}{c}{$\begin{array}{c}\text { Estimation of protein secondary } \\
\text { structure from CD spectra by K2 }\end{array}$} \\
\hline & ferm-flavoHb & flask-flavoHb \\
\hline$\alpha$-helix & $46 \%$ & $39 \%$ \\
\hline$\beta$-sheets & $23 \%$ & $17 \%$ \\
\hline random coil & $31 \%$ & $44 \%$ \\
\hline
\end{tabular}

Percentage of secondary structures was calculated from CD data spectra by K2d software (Merelo, Andrade). K2d offers an algorithm for the estimation of the percentages of protein secondary structure from UV circular dichroism spectra using a Kohonen neural network

In case of ferm-flavoHb secondary structure prediction, the program has given a maximum error of 0.080 . The maximum error obtained for flask-flavoHb secondary structure prediction is 0.085 . This means that the sum of the errors in the prediction of the alpha, beta and random percentage values divided by three is expected to be less then 0.085 . In both cases the error values are below the threshold maximal error 0.227. Maximal errors above this value indicate that the result given by the network prediction is not reliable.

residues are not solvent exposed. Both protein preparations were fully denatured by addition of guanidinium chloride (at a final concentration of $6 \mathrm{M}$ ) and the exposure of the tryptophan residues to a more polar environment was mirrored by the shift of the emission maximum to $366 \mathrm{~nm}$ (data not shown).

Spectra presented in figure 5 differ in the intensity of $\lambda_{\max }$ signal, where flask-flavoHb protein has a fluorescence emission at $338 \mathrm{~nm}$ about three times higher than that of ferm-flavoHb. To investigate if the FAD cofactor, which is present only in ferm-flavoHb protein, is responsible for the observed quenching of the signal at $338 \mathrm{~nm}$, tryptophan fluorescence spectra of flask-flavoHb were recorded in the presence of two molar ratio of exogenous FAD. As shown in figure 6 , the intensity of $\lambda_{\max }$ signal is not quenched by the addition FAD molecule, neither in the presence of the higher 1:1 FAD:protein molar ratio.

\section{Influence of different process parameters on inclusion bodies protein}

In order to understand which process parameter is more relevant in flavohemoglobin production, i.e. if the observed differences between flask-flavoHb and ferm-flavoHb depend on the SNP presence, on the bioreactor geometry, or on oxygen availability, three different production process setups were explored. The production of the PhflavoHb was carried out at $20^{\circ} \mathrm{C}$ in $7.5 \mathrm{~L}$ automatic fermenter, in microaerophilic conditions without SNP, in aerobic condition with and without SNP (always following the previously described induction conditions). Then, cells coming from the above production processes were analyzed and flavohemoglobin resulted to accumulate in inclusion bodies in all tested condition. P. haloplanktis TAC125 flavoHb IBs extracted from the different production processes were solubilized in presence of $0.2 \% \mathrm{~N}$-lauroyl sarcosine. As shown in Figure 7, the solubilized IBs produced in fermenter contain almost only the psychrophilic recombinant protein indicating that the different protein composition of solubilized IBs of flask-flavoHb and ferm-flavoHb (Figure 1) was due to the bioreactor geometry, i.e flask or automatic

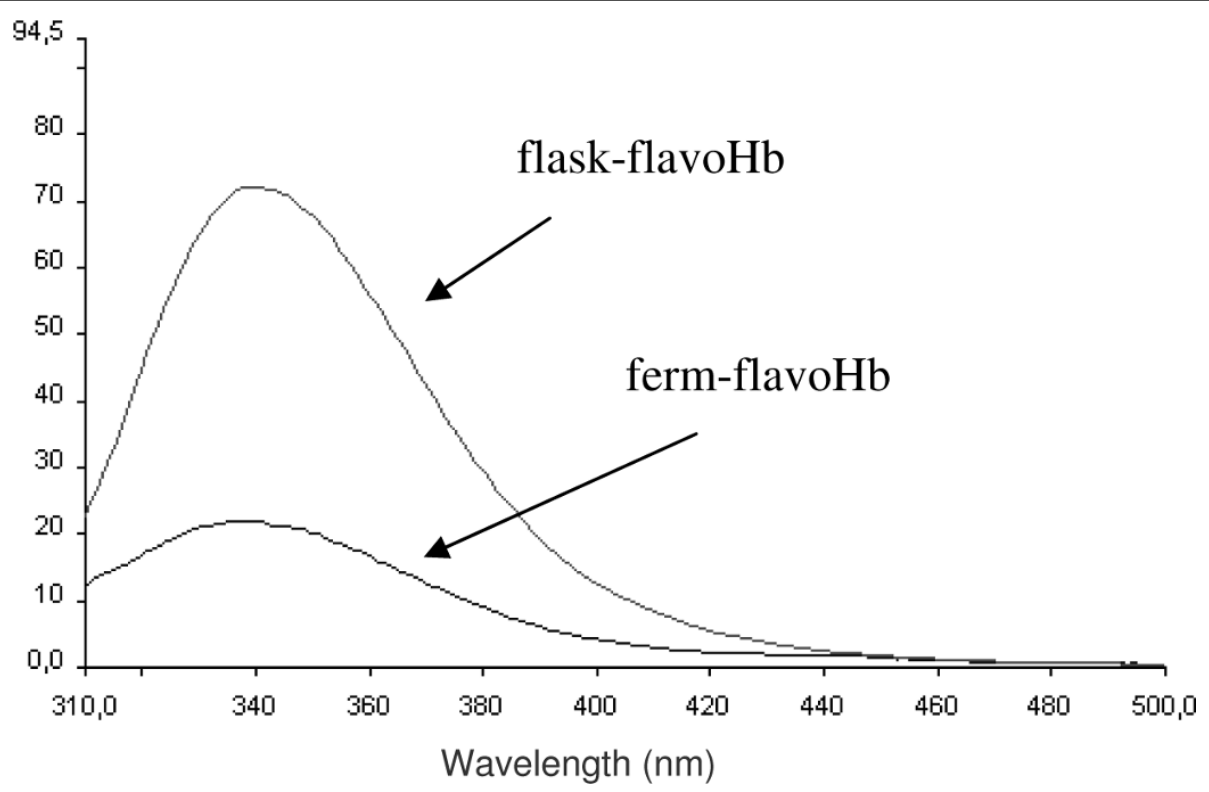

Figure 5 Tryptophan fluorescence spectra of ferm-flavoHb and flask-flavoHb. Fluorescence spectra of ferm flavoHb (A) and flask-flavoHb (B) obtained recording an emission spectra between $200 \mathrm{~nm}$ and $500 \mathrm{~nm}$ exciting at $295 \mathrm{~nm}$. Fluorescence spectra were recorded in $0.2 \% \mathrm{~N}$ lauroyl sarcosine, $40 \mathrm{mM}$ Tris/ $\mathrm{HCl} \mathrm{pH}$ 8.0, protein concentration was $2 \mu \mathrm{g} / \mu \mathrm{l}$. 


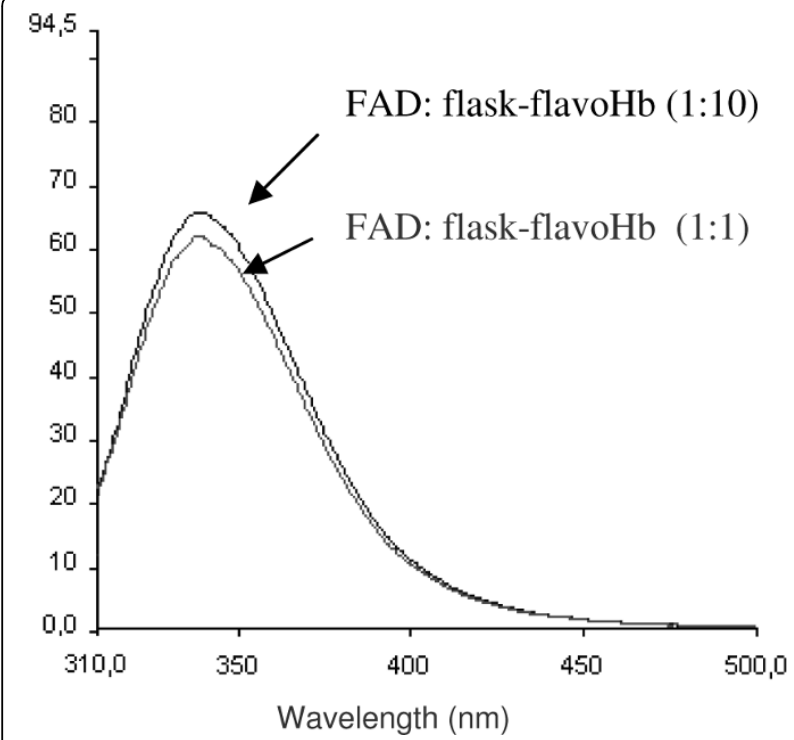

Figure 6 Tryptophan fluorescence spectra of flask-flavoHb in presence of FAD. Tryptophan fluorescence spectra of flask-flavo $\mathrm{Hb}$ in presence of FAD cofactor. FAD was added to flask-flavoHb protein at molar ratio of 1:10 and 1:1. Fluorescence spectra were recorded in $0.2 \%$ N-lauroyl sarcosine, $40 \mathrm{mM}$ Tris/ $\mathrm{HCl}$ pH 8.0, proteins concentration was $2 \mu \mathrm{g} / \mu \mathrm{l}$.

fermenter. The analyses aimed to investigate the presence of the heme and FAD (data not shown) demonstrated that proteins obtained in microaerophilic conditions without SNP and in aerobic condition with and without SNP lack of both cofactors.

\section{Discussion}

Several recent reports have shown that IBs could contain proteins that posses a native-like secondary structure and an enzymatic activity [3,5-7]. Moreover, it has been reported that IBs containing a high proportion of correctly folded protein can be easily solubilized under non-denaturing conditions [9]

In this paper we report a case in which using different process designs, we always obtained the complete accumulation of the recombinant proteins in IBs, from which the products were easily solubilized under nondenaturing conditions. Although their common attitude to get solubilized, recombinant proteins deriving from the different production processes differ in presence of cofactors and in their secondary and tertiary structure. In detail, we produced the flavohemoglobin from the Antarctic Gram-negative bacterium P. haloplanktis TAC125 [22] in E. coli cells in fermenter in the presence of a nitrosating compound (the SNP) and in microaerobiosis. In parallel, $\mathrm{PhflavoHb}$ was produced in E. coli recombinant cells in standard conditions, i.e. grown in shake flasks by an aerobic production scheme and in absence of SNP. Both processes, carried out at $20^{\circ} \mathrm{C}$, resulted in the total accumulation of the recombinant protein in cytoplasmic inclusion bodies. The treatment of ferm-flavoHb IBs and flask-flavoHb IBs with a $\mathrm{N}$-lauroyl sarcosine solution highlighted unexpected differences in i) the solubilization yield, and ii) the composition of the solubilized matter. This evidence prompted us to carry out a structural comparison of the two recombinant PhflavoHbs, in order to assess if the production setup could influence the main structural features of IBs proteins. Data reported in the present paper demonstrate that the two proteins differ significantly, mainly in the presence of FAD and heme cofactors. Indeed, when subjected to suitable spectroscopic analyses, proofs of the presence of heme and FAD were collected only in the case of ferm-flavoHb. Furthermore, CD spectra demonstrate that both proteins possess a secondary structure, but the ferm-flavoHb content of alpha-helix and beta-sheets is higher than that observed in the protein produced in flask.

Taking advantage from the presence of three tryptophan residues along the $P h f l a v o H b$ protein sequence, fluorescence emission spectra of tryptophan residues were recorded. Both spectra are characterized by a $\lambda_{\max }$ emission signal around $338 \mathrm{~nm}$, a result indicative that the Trp residues are not exposed to the solvent. Indeed, in these experimental conditions, unfolded proteins usually present a shift of $\lambda_{\text {max }}$ towards $350 \mathrm{~nm}$. As expected, when the proteins were chemically denatured by guanidinium chloride, a shift of the $\lambda_{\max }$ emission signal was observed (new maximum at $366 \mathrm{~nm}$, data not shown). These data are highly suggestive that both proteins display a 3D structure, although likely not identical. In fact, fluorescence intensity at $\lambda_{\max }$ of flask-flavoHb is about three times higher than that of the protein produced in fermenter. This different spectroscopic behaviour is not justified by the likely quenching effect of FAD cofactor associated only to the ferm-flavoHb. Therefore, the observed difference in intensity of $\lambda_{\text {max }}$ signal could be due to some amino acids residues close to tryptophan residues that work as fluorescence quencher in ferm-flavoHb. These results are suggestive of a different chemical surrounding around the tryptophan residues in flask-flavoHb and ferm-flavoHb proteins, thus supporting the conclusion that the two proteins differ in 3D structure too.

Furthermore, a systematic approach was applied to understand which process parameter was crucial for obtaining a protein endowed with FAD and heme cofactors. It turned out that the synergic effect of microareophilic growth conditions and the presence of SNP was essential. This experimental setup likely mimics the physiologic conditions in which flavoHb activity is required. The occurrence of a suitable physical-chemical environment and/or the induction of specific protein chaperones could justify the unique cofactors incorporation observed. 


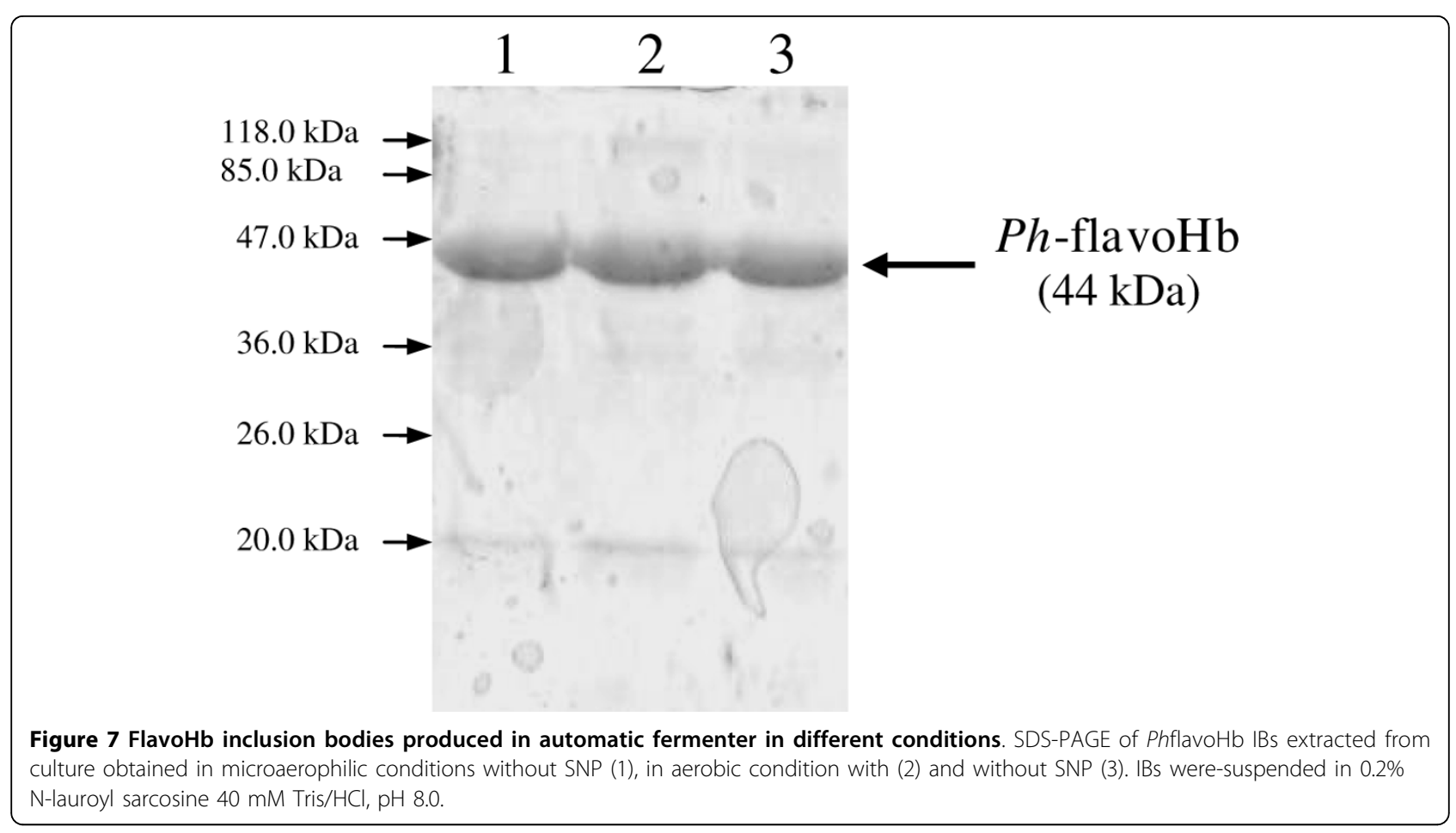

Without a structural/functional characterization of native $P h f l a v o H b$, a final assessment on the quality of the recombinant proteins produced in this work cannot be formulated. However, the presence of FAD and heme cofactors, together with the collected indirect evidences of a different secondary and, eventually, tertiary structures, looks very promising of a better quality of flavoHb obtained in the presence of a nitrosating compound and in microaerobiosis.

\section{Conclusions}

The present paper describes the recombinant production of a flavohemoglobin, a multidomain protein requiring $\mathrm{FAD}$ and heme cofactors for its activity. Two significantly different production process designs were explored, both resulting in the full product accumulation in IBs. Data reported here demonstrate that other process parameters, besides growth temperature, influence the quality of a recombinant product even if it accumulates in IBs. To the best of our knowledge, this is the first reported example in which the quality of protein solubilized from inclusion bodies has been correlated to the production process design.

\section{Methods}

\section{Bacterial strains, plasmid and culture condition}

The E. coli BL21(DE3) (Novagen) strain was routinely used for cloning and expressing recombinant gene. Cells were grown in Luria-Bertani (LB) medium at $20^{\circ} \mathrm{C}$. When required, ampicillin (Sigma) was added at $100 \mu \mathrm{g} /$ ml. Plasmid pET-22b (Novagen) was utilized for cloning and expression. Restriction and modifying enzymes were obtained from Promega. The oligonucleotides were custom synthesized from PRIMM.

\section{Cloning of the PSHAa2880gene}

The primer pairs for the PSHAa2880 gene (Oligo 2880 fw 5' TTCATATGTTATCTGATAAAACTATTGAAA 3', Oligo 2880 rv 5' AAGTCGACTTATAGATCTTGATGCGG 3') were designed on the basis of the $P$. haloplanktis TAC125-genome sequence [31]. Sequences corresponding to the NdeI site and a SalI site were introduced in the forward and reverse primers, respectively. The amplifications were performed in a mixture containing $80 \mathrm{ng}$ of $P$. haloplanktis TAC125-genomic DNA as template, 50 pmol of each oligonucleotide primer, $1.8 \mathrm{mM} \mathrm{MgCl} 2,50 \mathrm{mM} \mathrm{KCl}, 20 \mathrm{mM}$ Tris- $\mathrm{HCl} \mathrm{pH}$ 8.3, $0.1 \%$ gelatine, $200 \mu \mathrm{M}$ dNTP in a final volume of 50 $\mu \mathrm{l}$. The mixtures were incubated at $95^{\circ} \mathrm{C}$ for $10 \mathrm{~min}$, then 1.25 units of Taq DNA polymerase were added. Twenty cycles of amplification (consisting of $1 \mathrm{~min}$ at $95^{\circ} \mathrm{C}, 1.5 \mathrm{~min}$ at $60^{\circ} \mathrm{C}$ and $1 \mathrm{~min}$ plus $5 \mathrm{sec} / \mathrm{cycle}$ at $72^{\circ}$ C) were carried out and followed by a cycle in which the extension reaction at $72^{\circ} \mathrm{C}$ was prolonged for 15 min in order to complete DNA synthesis. The amplified fragment was cloned and its nucleotide sequence checked to rule out the occurrence of any mutation during synthesis. The NdeI-SalI-digested fragment of the PSHAa2880 gene was then subcloned into the corresponding sites of the expression vector pET-22b, 
obtaining the plasmid pET22b-2880. The recombinant vector was used to transform $E$. coli BL21(DE3) cells, that were used for the following production processes. All DNA manipulation were performed as previously described [32]

\section{Shake Flask Culture}

For the over-expression of cold-adapted flavoHb in flask, a single colony of recombinant E. coli BL21(DE3) (pET22b-2880) was inoculated in LB medium supplemented with $4 \mathrm{~g} / \mathrm{L}$ glucose and ampicillin $(100 \mu \mathrm{g} / \mathrm{ml})$ and allowed to grow at $20^{\circ} \mathrm{C}$, in the rotary shaker, until absorbance at $600 \mathrm{~nm}$ reached $\sim 0.6 \mathrm{OD}$. The culture was then induced with $1 \mathrm{mM}$ isopropyl- $\beta$-D-thiogalactopyranoside and further incubated for another $16-18 \mathrm{~h}$ at $20^{\circ} \mathrm{C}$ in the presence of $50 \mu \mathrm{M}$ of D-aminolevulinic acid, $3 \mu \mathrm{M} \mathrm{FeCl}_{3}, 100 \mu \mathrm{M}$ riboflavin. After production, the cell culture was aliquoted, centrifuged, and the supernatant was discarded. The bacterial pellet was stored for further analysis.

\section{Laboratory Fermentation}

A proper preinoculum of overnight grown recombinant E. coli BL21(DE3) (pET22b-2880) was diluted in $4.5 \mathrm{~L}$ of LB medium supplemented with $4 \mathrm{~g} / \mathrm{L}$ glucose and ampicillin $(100 \mu \mathrm{g} / \mathrm{ml})$ in a 7.5 -L Techfors $S$ (Infors, HT Switzerland) automatic fermenter. Cells were grown aerobically at $20^{\circ} \mathrm{C}$ till the culture density reached the value of $0.6 \mathrm{OD}$ at $600 \mathrm{~nm}$. Induction was then performed by $1 \mathrm{mM}$ IPTG, in the presence of $50 \mu \mathrm{M} \mathrm{mM}$ D-aminolevulinic acid, $3 \mu \mathrm{M} \mathrm{FeCl}, 100 \mu \mathrm{M}$ riboflavin and $0.4 \mathrm{mM}$ sodium nitroprusside (SNP). Then, air supply was stopped during the next 16-18 hr of fermentation keeping a microaerophilic conditions (dissolved oxygen tension always below $5 \%$ of saturation).

In case of production of the PhflavoHb in aerobic condition with and without SNP the preinoculum of overnight grown recombinant $E$. coli BL21(DE3) (pET22b-2880) was diluted in $2.5 \mathrm{~L}$ of medium and dissolved oxygen tension was maintained always above $30 \%$ of saturation.

After production, the cell culture was collected, centrifuged, and the supernatant was discarded. The bacterial pellet was stored for further analysis.

\section{Protein inclusion bodies extraction}

Biomass was harvested at the end of the production process by centrifugation, and the wet bacterial pellet was re-suspended in $10 \mathrm{mM}$ Tris $/ \mathrm{HCl}, \mathrm{pH}$ 8.0. Samples were kept on ice and disrupted by sonication using an Branson sonicator (Model B-15), using a program consisting of 20 cycles (30" on, 60" off, intensity 4.5). After disruption of the cells, samples were centrifuged at 5000 $\mathrm{rpm}$ for $30 \mathrm{~min}$ at a constant temperature of $4^{\circ} \mathrm{C}$. The supernatant was discarded, and the inclusion bodies fraction was washed twice with chilled water, divided in several aliquots and incubated overnight for the solubilization at $4^{\circ} \mathrm{C}$ in $40 \mathrm{mM}$ Tris $/ \mathrm{HCl}, \mathrm{pH} 8.0$ buffer containing alternatively:

- $5 \%$ n-propanol;

- $0.5 \%$ Triton X-100;

- 5\% DMSO;

- $1 \%$ Na-deoxycholate;

- $0.2 \%$ N-lauroyl sarcosine.

As negative control the insoluble matter was treated with water. After the incubation, the suspensions were centrifuged at $4400 \times \boldsymbol{g}$ for 15 minutes at $4^{\circ} \mathrm{C}$. The supernatants were analyzed by SDS-PAGE.

\section{Protein concentration measurements}

The Bradford method [33] was applied to determine protein concentration. In case of protein solubilized from IBs with different solvents a qualitative measure of protein content was determined by measuring the amount of light absorbed at $280 \mathrm{~nm}$ (Abs280).

\section{Spectroscopic Measurements}

UV-Vis absorption spectra were recorded in UNIKON 930 spectrophotometer. Fluorescence measurements were carried out in a PERKIN ELMER LS 50B fluorospectrometer. Circular dichroism (CD) spectra were obtained in a Jasco spectropolarimeter (model J-715) equipped with a thermostatically controlled cell holder.

\section{Acknowledgements}

We are grateful to Prof. Leila Birolo (Dipartimento di Chimica Organica e Biochimica, Università degli Studi di Napoli Federico II Napoli Italia) for critical reading of the manuscript and very helpful discussions. Thank to Rosaria Varlese for her excellent technical support with the fermentation units. This work was supported by grant of Programma Nazionale di Ricerca in Antartide 2004 (Prof. Marino) and Ministero dell'Università e della Ricerca Scientifica (Progetti di Rilevante Interesse Nazionale 2007 - Prof. Di Donato).

\section{Author details}

'Department of Organic Chemistry and Biochemistry, Università degli studi di Napoli Federico II - Complesso Universitario M.S. Angelo via Cinthia 4, 80126, Naples, Italy. ${ }^{2}$ Facoltà di Scienze Biotecnologiche, Università degli studi di Napoli Federico II, Naples, Italy.

\section{Authors' contributions}

EP and MG performed the experiments and helped to draft the manuscript. EP and MLT drafted the manuscript and designed and coordinated the study. GM has been involved in manuscript preparation and critical reading. All authors read and approved the manuscript.

\section{Competing interests}

The authors declare that they have no competing interests.

Received: 29 October 2009 Accepted: 24 March 2010 Published: 24 March 2010

\section{References}

1. Schlieker C, Bukau B, Mogk A: Prevention and reversion of protein aggregation by molecular chaperones in the $\mathrm{E}$. coli cytosol: implications for their applicability in biotechnology. J Biotechnol 2002, 96:13-21. 
2. Marston FA: The purification of eukaryotic polypeptides synthesized in Escherichia coli. Biochem J 1986, 240:1-12.

3. Garcia-Fruitos E, Gonzalez-Montalban N, Morell M, Vera A, Ferraz RM, Aris A, Ventura S, Villaverde A: Aggregation as bacterial inclusion bodies does not imply inactivation of enzymes and fluorescent proteins. Microb Cell Fact 2005, 4:27.

4. Ventura S, Villaverde A: Protein quality in bacterial inclusion bodies. Trends Biotechnol 2006, 24:179-185.

5. Ami D, Natalello A, Taylor G, Tonon G, Doglia SM: Structural analysis of protein inclusion bodies by Fourier transform infrared microspectroscopy. Biochim Biophys Acta 2006, 1764:793-799.

6. Gonzalez-Montalban N, Garcia-Fruitos E, Ventura S, Aris A, Villaverde A: The chaperone DnaK controls the fractioning of functional protein between soluble and insoluble cell fractions in inclusion body-forming cells. Microb Cell Fact 2006, 5:26.

7. Arie JP, Miot M, Sassoon N, Betton JM: Formation of active inclusion bodies in the periplasm of Escherichia coli. Mol Microbiol 2006, 62:427-437.

8. Gonzalez-Montalban N, Garcia-Fruitos E, Villaverde A: Recombinant protein solubility-does more mean better? Nat Biotechnol 2007, 25:718-720.

9. Jevsevar S, Gaberc-Porekar V, Fonda I, Podobnik B, Grdadolnik J, Menart V: Production of nonclassical inclusion bodies from which correctly folded protein can be extracted. Biotechnol Prog 2005, 21:632-639.

10. Garcia-Fruitos E, Carrio MM, Aris A, Villaverde A: Folding of misfoldingprone beta-galactosidase in absence of DnaK. Biotechnol Bioeng 2005, 90:869-875.

11. Ermler U, Siddiqui RA, Cramm R, Friedrich B: Crystal structure of the flavohemoglobin from Alcaligenes eutrophus at $1.75 \mathrm{~A}$ resolution. EMBO J 1995, 14:6067-6077.

12. Liu L, Zeng M, Hausladen A, Heitman J, Stamler JS: Protection from nitrosative stress by yeast flavohemoglobin. Proc Natl Acad Sci 2000, 97:4672-4676.

13. Tarricone C, Galizzi A, Coda A, Ascenzi P, Bolognesi M: Unusual structure of the oxygen-binding site in the dimeric bacterial hemoglobin from Vitreoscilla sp. Structure 1997, 975:497-507.

14. Poole RK, loannidis N, Orii Y: Reactions of the Escherichia coli flavohaemoglobin ( $\mathrm{Hmp}$ ) with oxygen and reduced nicotinamide adenine dinucleotide: evidence for oxygen switching of flavin oxidoreduction and a mechanism for oxygen sensing. Proc Biol Sci 1994 255:251-258

15. Andrews SC, Shipley D, Keen JN, Findlay JB, Harrison PM, Guest JR: The haemoglobin-like protein (HMP) of Escherichia coli has ferrisiderophore reductase activity and its C-terminal domain shares homology with ferredoxin NADP ${ }^{+}$reductases. FEBS Lett 1992, 302:247-252.

16. Gardner PR, Gardner AM, Martin LA, Salzman AL: Nitric oxide dioxygenase: an enzymic function for flavohemoglobin. Proc Natl Acad Sci 1998, 95:10378-10383.

17. Hausladen A, Gow AJ, Stamler JS: Nitrosative stress: metabolic pathway involving the flavohemoglobin. Pro Nat Acad Sci 1998, 95:14100-14105.

18. Crawford MJ, Goldberg DE: Regulation of the Salmonella typhimurium flavohemoglobin gene. A new pathway for bacterial gene expression in response to nitric oxide. J Biol Chem 1998, 273:34028-32.

19. Membrillo-Hernández J, Coopamah MD, Anjum MF, Stevanin TM, Kelly A, Hughes MN, Poole RK: The flavohemoglobin of Escherichia coli confers resistance to a nitrosating agent, a "Nitric oxide Releaser," and paraquat and is essential for transcriptional responses to oxidative stress. J Biol Chem 1999, 274:748-754.

20. Hausladen A, Gow A, Stamler JS: Flavohemoglobin denitrosylase catalyzes the reaction of a nitroxyl equivalent with molecular oxygen. Proc Natl Acad Sci 2001, 98:10108-10112.

21. Kim SO, Orii Y, Lloyd D, Hughes MN, Poole RK: Anoxic function for the Escherichia coli flavohaemoglobin ( $\mathrm{Hmp}$ ): reversible binding of nitric oxide and reduction to nitrousoxide. FEBS Lett 1999, 445:389-394.

22. Giordano D, Parrilli E, Dettaï A, Russo R, Barbiero G, Marino G, Lecointre G, di Prisco G, Tutino ML, Verde $C$ : The truncated hemoglobins in the Antarctic psychrophilic bacterium Pseudoalteromonas haloplanktis TAC125. Gene 2007, 398:69-77.

23. Spiro S: Regulators of bacterial responses to nitric oxide. FEMS Microbial rev 2007, 31:193-211.
24. Wu G, Corker H, Orii Y, Poole RK: Escherichia coli Hmp, an "oxygenbinding flavohaemoprotein", produces superoxide anion and selfdestructs. Arch Microbiol 2004, 182:193-203.

25. Membrillo-Hernández J, loannidis N, Poole RK: The flavohaemoglobin (HMP) of Escherichia coli generates superoxide in vitro and causes oxidative stress in vivo. FEBS Lett 1996, 382:141-4.

26. Lewis ME, Corker HA, Gollan B, Poole RK: A survey of methods for the purification of microbial flavohemoglobins. Methods Enzymol 2008, 436:169-86.

27. Gardner AM, Martin LA, Gardner PR, Dou Y, Olson JS: Steady-state and transient kinetics of Escherichia coli nitric-oxide dioxygenase (flavohemoglobin). The B10 tyrosine hydroxyl is essential for dioxygen binding and catalysis. J Biol Chem 2000, 275:12581-9.

28. Marx JC, Collins T, D'Amico S, Feller G, Gerday C: Cold-adapted enzymes from marine Antarctic microorganisms. Mar Biotechnol 2007, 9:293-304.

29. Andrade A, Chacón P, Merelo JJ, Morán F: Evaluation of secondary structure of proteins from UV circular dichroism using an unsupervised learning neural network. Prot Eng 1993, 6:383-390.

30. Merelo JJ, Andrade MA, Prieto A, Morán F: Proteinotopic Feature Maps. Neurocomputing 1994, 6:443-454.

31. Médigue C, Krin E, Pascal G, Barbe V, Bernsel A, Bertin PN, Cheung F, Cruveiller S, D'Amico S, Duilio A, Fang G, Feller G, Ho C, Mangenot S, Marino G, Nilsson J, Parrilli E, Rocha EP, Rouy Z, Sekowska A, Tutino ML, Vallenet $D$, von Heijne $G$, Danchin $A$ : Coping with cold: the genome of the versatile marine Antarctica bacterium Pseudoalteromonas haloplanktis TAC125. Genome Res 2005, 15:1325-35.

32. Sambrook J, Russell DW: Molecular Cloning. A Laboratory Manual Cold Spring Harbor Laboratory, Cold Spring Harbor, NY, 32001.

33. Bradford M: A Rapid and Sensitive Method for the Quantitation of Microgram Quantities of Protein Utilizing the Principle of Protein-Dye Binding. Anal Biochem 1976, 72:248-254.

doi:10.1186/1475-2859-9-19

Cite this article as: Parrilli et al:: Influence of production process design on inclusion bodies protein: the case of an Antarctic flavohemoglobin. Microbial Cell Factories 2010 9:19.

\section{Submit your next manuscript to BioMed Central and take full advantage of:}

- Convenient online submission

- Thorough peer review

- No space constraints or color figure charges

- Immediate publication on acceptance

- Inclusion in PubMed, CAS, Scopus and Google Scholar

- Research which is freely available for redistribution

Submit your manuscript at www.biomedcentral.com/submit
Biomed Central 